\title{
Bioethics and Its Gatekeepers: Does Institutional Racism Exist in Leading Bioethics Journals?
}

\author{
Subrata Chattopadhyay • Catherine Myser • \\ Raymond De Vries
}

Received: 8 September 2012 / Accepted: 8 November 2012 / Published online: 24 January 2013

(C) Springer Science+Business Media Dordrecht 2013

\begin{abstract}
Who are the gatekeepers in bioethics? Does editorial bias or institutional racism exist in leading bioethics journals? We analyzed the composition of the editorial boards of 14 leading bioethics journals by country. Categorizing these countries according to their
\end{abstract}

S. Chattopadhyay $(\bowtie)$

Department of Physiology and Institutional Ethics

Committee, Sikkim Manipal Institute of Medical Sciences, 5th Mile, Tadong,

Gangtok, Sikkim 737102, India

e-mail: linkdrsc@yahoo.com

S. Chattopadhyay

e-mail: linkdrsc@gmail.com

C. Myser

Ethics, Social Medicine, and Global Health Programs, Charles E. Schmidt College of Medicine, Florida Atlantic University,

777 Glades Road, Building BC-71, Office 118,

Boca Raton, FL 33431, USA

e-mail: cmyser@fau.edu

C. Myser

e-mail: catmyser@hotmail.com

R. De Vries

Center for Bioethics and Social Sciences in Medicine, University of Michigan,

300 North Ingalls Street, Room 7C27,

Ann Arbor, MI 48109-5429, USA

R. De Vries

CAPHRI School for Public Health and Primary Care,

Maastricht University,

Maastricht, The Netherlands

e-mail: rdevries@med.umich.edu
Human Development Index (HDI), we discovered that approximately 95 percent of editorial board members are based in (very) high-HDI countries, less than 4 percent are from medium-HDI countries, and fewer than 1.5 percent are from low-HDI countries. Eight out of 14 leading bioethics journals have no editorial board members from a medium- or low-HDI country. Eleven bioethics journals have no board members from low-HDI countries. This severe underrepresentation of bioethics scholars from developing countries on editorial boards suggests that bioethics may be affected by institutional racism, raising significant questions about the ethics of bioethics in a global context.

Keywords Bioethics - Ethics - Editorial bias ·

Medicine $\cdot$ Institutional racism

Health care research, policy discussions, and debates are notorious for their failure to address the problems of those who suffer the most. Leading medical journals systematically neglect to cover the diseases of poverty that afflict larger humanity (Horton 2003); health professionals from developing countries constitute a tiny minority of research authors (Sumathipala, Siribaddana, and Patel 2004); and major medical journals have few, if any, editorial board members from developing countries (Horton 2003; Saxena et al. 2003; Tutarel 2005). But surely journals concerned with ethics in medicine are an exception to such exclusions and inequities. Or are they?

Scanning 4,029 research articles in nine bioethics journals, Borry, Schotsmans, and Dierickx (2005) 
Table 1 Composition of editorial and advisory board members of 14 leading bioethics journals

\begin{tabular}{|c|c|c|c|c|}
\hline \multirow[t]{2}{*}{ Name of the Journal } & \multirow{2}{*}{$\begin{array}{l}\text { Total number of } \\
\text { members of editorial } \\
\text { and advisory boards }^{\mathrm{a}}\end{array}$} & \multicolumn{3}{|c|}{$\begin{array}{l}\text { Number of members located in countries with Very High/High/Medium/Low } \\
\text { Human Development Index (HDI) }{ }^{b}\end{array}$} \\
\hline & & $\begin{array}{l}\text { Very High and } \\
\text { High HDI }\end{array}$ & Medium HDI & Low HDI \\
\hline American Journal of Bioethics & 40 & $38(95 \%)$ & $2(5 \%)$ (Thailand, India) & 0 \\
\hline Bioethics & 47 & $47(100 \%)$ & 0 & 0 \\
\hline BMC Medical Ethics & 21 & $18(85.7 \%)$ & 1 (4.7%) (Philippines) & $\begin{array}{l}2(9.5 \%) \text { (Cameroon, } \\
\text { Zimbabwe })\end{array}$ \\
\hline $\begin{array}{l}\text { Cambridge Quarterly of } \\
\text { Healthcare Ethics }\end{array}$ & 36 & $36(100 \%)$ & 0 & 0 \\
\hline The Hastings Center Report & 8 & $8(100 \%)$ & 0 & 0 \\
\hline Journal of Bioethical Inquiry & 64 & $59(92.2 \%)$ & $\begin{array}{l}5(7.8 \%) \text { (3 from South } \\
\text { Africa; } 1 \text { each from } \\
\text { China and Philippines })\end{array}$ & 0 \\
\hline Journal of Clinical Ethics & 29 & $29(100 \%)$ & 0 & 0 \\
\hline $\begin{array}{l}\text { Journal of Law, Medicine } \\
\text { and Ethics }\end{array}$ & 46 & $46(100 \%)$ & 0 & 0 \\
\hline Journal of Medical Ethics & 25 & $25(100 \%)$ & 0 & 0 \\
\hline $\begin{array}{l}\text { Journal of Medicine and } \\
\text { Philosophy }\end{array}$ & 69 & $67(97.1 \%)$ & $2(2.9 \%)($ China $)$ & 0 \\
\hline $\begin{array}{l}\text { The Kennedy Institute of } \\
\text { Ethics Journal }\end{array}$ & 23 & $23(100 \%)$ & 0 & 0 \\
\hline $\begin{array}{l}\text { Medicine Health Care and } \\
\text { Philosophy }\end{array}$ & 45 & $45(100 \%)$ & 0 & 0 \\
\hline $\begin{array}{l}\text { Theoretical Medicine and } \\
\text { Bioethics }\end{array}$ & 38 & $37(97 \%)$ & 0 & $1(3 \%)$ (Malawi) \\
\hline Developing World Bioethics & 36 & $23(63.8 \%)$ & $\begin{array}{l}9(25 \%) \text { (5 from South Africa; } \\
1 \text { each from India, China, } \\
\text { Sri Lanka, Philippines })\end{array}$ & $\begin{array}{l}4 \text { (11.1\%) (Bangladesh, } \\
\text { Cameroon, Nigeria, } \\
\text { Tanzania) }\end{array}$ \\
\hline Total & $527^{\mathrm{c}}$ & $501(95 \%)$ & $19(3.6 \%)$ & $7(1.3 \%)$ \\
\hline
\end{tabular}

${ }^{a}$ Includes editor-in-chief, editor, co-editor, executive editor, managing editor, contributing editor, (international) associate editor, book review editor, editorial committee, editorial board, editorial advisory board, and editorial assistant as listed in individual journals

${ }^{\mathrm{b}}$ Countries were classified according to their Human Development Index (Human Development Report 2011). The percentages are given in brackets

${ }^{\mathrm{c}}$ Some members have redoubled influence by serving on the editorial and advisory boards of more than one bioethics journal, yet again multiplying the exclusion of would be developing country board members

found that developing country scholars contributed fewer than 4 percent of publications (the other 96 percent coming from authors working in developed countries). It is no surprise, then, that bioethics pays more attention to esoteric ethical problems facing wealthy nations than it does to issues such as poverty, hunger, and health inequities that are global in nature (Turner 2004). Is this editorial bias (Lancet editor Richard Horton calls this institutional racism) mirrored in the editorial boards of leading bioethics journals?

We analyzed the composition of editorial boards of 14 leading bioethics journals by country (Table 1), as recorded on journal websites, categorizing these countries according to their Human Development Index (HDI). ${ }^{1}$ Approximately 95 percent of editorial board members are based in (very) high-HDI countries, less than 4 percent are from medium-HDI countries, and fewer than 1.5 percent are from lowHDI countries. Eight out of 14 leading bioethics jour-

\footnotetext{
${ }^{1}$ The Human Development Index (HDI) is a composite measure of four indicators-life expectancy at birth, mean years of schooling, expected years of schooling, and gross national income per capita - reflecting three dimensions of human development, i.e., health, education, and living standards. (See http:// hdr.undp.org/en/statistics/hdi for more information.)
} 
nals have no medium- or low-HDI country editorial board membership. Eleven bioethics journals in our sample of 14 have no board members from any lowHDI country.

This severe underrepresentation of developing countries on editorial boards suggests that institutional racism also infects leading bioethics journals and is clearly a cause for concern. With bioethics increasingly part of the global landscape of health care - more so since the 2005 promulgation of the Universal Declaration on Bioethics and Human Rights - the lack of global representation on bioethics journal editorial boards undermines consideration of developing country experiences and knowledge, impoverishing global bioethics. Citizens of countries in the developing world are thus dependent on those who can envision and empathize with the harsh realities affecting "others" and who are willing and able to muster global social justice resources to remedy them. Global health and ethics are far more effectively served by egalitarian partnerships between local and global experts working together to identify and reduce health inequities in culturally competent ways. Bioethics journals must open their pages to the whole of humanity.
Competing Interests None.

Funding Support None.

\section{References}

Borry, P., P. Schotsmans, and K. Dierickx. 2005. Developing countries and bioethical research. The New England Journal of Medicine 353(8): 852-853.

Horton, R. 2003. Medical journals: Evidence of bias against the diseases of poverty. The Lancet 361(9359): 712-713.

Human Development Report. 2011. Sustainability and equity: A better future for all. New York: United Nations Development Programme. http://hdr.undp.org/en/media/HDR 2011_EN_Complete.pdf.

Saxena, S., I. Levav, P. Maulik, and B. Saraceno. 2003. How international are the editorial boards of leading psychiatry journals? The Lancet 361(9357): 609.

Sumathipala, A., S. Siribaddana, and V. Patel. 2004. Underrepresentation of developing countries in the research literature: Ethical issues arising from a survey of five leading medical journals. BMC Medical Ethics 5(October 4): E5. doi:10.1186/1472-6939-5-5.

Turner, L. 2004. Bioethics needs to rethink its agenda. BMJ 328(7432): 175 .

Tutarel, O. 2005. How international are leading general paediatric journals? Archives of Disease in Childhood 90(8): 816-817. 